\title{
PENGEMBANGAN E-MODUL BERBASIS DISCOVERY LEARNING PADA PEMBELAJARAN TEMATIK TEMA 6 SUBTEMA 1 HEWAN DI SEKITAR KU SD KELAS II
}

\author{
Nini Sonia, Nila Kesumawati, Nora Sulmilasari \\ Surel: ninisonia16@gmail.com
}

\begin{abstract}
This study aims to produce an E-Module based on discovery learning in thematic learning of theme 6 sub-theme 1 for class II SD which is valid and practical and to determine the potential effects of development. This research is included in research and development, referring to the development of ADDIE. The research took place at SDN 199 Palembang. The research subjects were 24 second grade elementary school students. Data collection was carried out by means of a media and language expert validation questionnaire, material expert, mathematics teacher questionnaire, student response questionnaire, and student test result data. The data were analyzed quantitatively and qualitatively. The results showed that the validation of the validators got an average validation score of $88.66 \%$ with a valid category. The results of student responses based on trials got an average score of $91.58 \%$ in the practical category. The results of the test questions distributed to 24 students contained 21 students who completed and 3 students did not complete, the average student score was $84.50 \%$ in the very good category or had a potential effect on student learning outcomes.
\end{abstract}

Keywords: E-Module, ADDIE, Discovery Learning, Thematic Theme 6 Subtheme 1

\begin{abstract}
ABSTRAK
Penelitian ini bertujuan untuk menghasilkan E-Modul berbasis discovery learning pada pembelajaran tematik tema 6 subtema 1 untuk kelas II SD yang valid dan praktis serta untuk mengetahui Efek Potensial pengembangan. Penelitian ini termasuk dalam penelitian dan pengembangan, mengacu pada pengembangan ADDIE. Penelitian bertempat di SDN 199 Palembang. Subjek penelitian yaitu 24 siswa kelas II SD. Pengumpulan data dilakukan dengan angket validasi ahli media dan bahasa, ahli materi, angket guru mata pelajaran matematika, angket respons siswa, dan data hasil tes soal siswa. Data di analisis secara kuantitatif dan kualitatif. Hasil penelitian menunjukkan bahwa validasi para validator mendapat skor rata-rata validasi $88,66 \%$ dengan kategori valid. Hasil respons siswa berdasarkan uji coba mendapatkan skor rata-rata 91,58\% dengan kategori praktis. Hasil tes soal yang dibagikan kepada 24 siswa terdapat 21 siswa tuntas dan 3 siswa belum tuntas, rata-rata nilai siswa sebesar $84,50 \%$ dengan kategori sangat baik atau memiliki efek potensial terhadap hasil belajar siswa.
\end{abstract}

Kata Kunci: E-Modul, ADDIE, Discovery Learning, Tematik Tema 6 Subtema 1 
Nini Sonia, Nila Kesumawati, Nora Sulmilasari : Pengembangan E-Modul ...

PENDAHULUAN

Pendidikan di Indonesia tidak terlepasan dari pengawasan pemerintah dilihat dari apa yang telah dilakukan pemerintah untuk memperbaiki kualitas pendidikan salah satunya bukti yaitu memperbaiki kurikulum pendidikan. Kurikulum pendidikan pada saat ini yang digunakan adalah kurikulum 2013. Dalam kurikulum 2013 model pembelajaran tematik menjadi sebuah tuntunan sekaligus kebutuhan utama pada sekolah dasar atau madrasah ibtidaiyah. Pembelajaran tematik intergratif ini merupakan pendekatan pembelajaran yang mengitergarasikan berbagai kompetensi dari berbagai mata pelajaran ke dalam berbagai tema. Pengintergrasian ini dilakukan melalui pendekatan intradispliner, multidispliner, interdispliner, dan trandsipliner. (Prastowo, 2014). Pembelajaran tematik adalah pembelajaran yang memaduhkan antara berbagai mata pelajaran atau bidang studi dengan menggunakan tema tertentu.

Tema tersebut kemudian diulas atau dielaborasi dari berbagai sudut pandang ilmu pengetahuan social, ilmu pengetahuan alam, humaniora maupun agama sehingga memberikan pengalaman yang bermakna bagi peserta didik. Dengan pembelajaraan tematik anak didik diharapkan mendapatkan hasil belajar yang optimal dan maksimal dan menghindari kegagalan pembelajaran yang masih banyak terjadi dengan model pembelajaran yang lain (Asrohah, 2014, p. 9). Pembelajaran tematik dikurikulum 2013 ini ruang lingkupnya jauh lebih luas karena untuk kelas I sampai VI disekolah dasar. Salah satu tema didalam pembelajaran sekolah dasar yaitu tema 6 subtema 1 Hewan disekitarku terdapat dikelas II.

Berdasarkan observasi yang peneliti lakukan di SD Negeri 079 Prabumulih dan pengalaman PPL ditemukan bahwa guru masih menggunakan pendekatan konvensional yaitu guru adalah satusatunya informan dalam pembelajaran, guru menyampaikan informasi sedangkan siswa hanya menerima informasi, siswa dilatih mengerjakan soal tanpa pemahaman dan siswa kurang dilibatkan dalam proses pembelajaran. Sehingga karakteristik cenderung memiliki sikap kurang tanggap/ aktif dan mandiri mengakibatkan hasil belajar siswa rendah. Pendidik hanya mengandalkan buku paket dari pemerintah hal ini terlihat kurangnya kreaktifitas dan pemahaman guru dalam mengembangkan bahan ajar yang dapat memfasilitasi keaktifan dan kemandirian siswa.

Menurut

Supardi

(Sulistyosari, 2018) kurangnya kreaktifitas guru dalam mengembangkan banyak terjadi, hal tersebut dikarenakan kurangnya pemahaman guru terhadap bahan ajar yang sesuai dilakukan setiap proses pembelajaran sehingga tidak berjalan dengan efesien untuk itu guru dituntut lebih kreaktif dalam menciptakan bahan ajar yang baru untuk membantu peserta didik memahami materi yang 
di sampaikan oleh guru. Karena guru mempunyai peran penting untuk menciptakan pembelajaran yang kreaktif melalui perencanaan yang dilakukan dengan membuat perangkat salah satunya pembuatan bahan ajar yang berbentuk e-modul. Pengembangan e-modul dapat dilakukan dengan cara mengembangkan topik atau tema tertentu, kemudian dilengkapi, diperluas, dan diperdalam dengan cabang-cabang ilmu yang lain.

Untuk memfasilitasi keaktifan dan kemandirian siswa dalam proses pembelajaran, tentunya dibutuhkan pendekatan yang tepat. Salah satu pendekatan yang diduga tepat untuk memfasilitasinya yaitu pendekatan discovery learning. Discovery Learning adalah salah satu pendekatan pembelajaran yang digunakan dalam proses pembelajaran disekolah. Pendekatan discovery learning mengajarkan kepada peserta didik untuk aktif dalam proses pembelajaran. Peserta didik diharapkan bisa mengembangkan atau menemukan hal baru atau pengetahuan baru apa yang sudah diberikan oleh pendidik. Hal ini didukung oleh penelitian Hermawan, (2015) bahwa data hasil penelitian menunjukan adanya peningkatan kemandirian siswa melalui pendekatan discovery learning.

Pengembangan e-modul berbasisis discovery learning ini dapat membantu mengembangkan keaktifan dan kemandirian siswa hal ini dibuktikan oleh penelitian (Muslimah, 2019) mengemukakan bahwa e-modul berbasisis discovery learning dapat membantu siswa dalam memahami materi, dengan Discovery Learning siswa dapat belajar secara mandiri dengan menggunkan e-modul pembelajran sehingga dapat dikatagorikan produk dalam keadaan layak digunakan.

Penelitian yang dilakukan oleh (Febrianti \& dkk, 2017) mengemukakan bahwa berdasarkan hasil analisisi kebutuhan peserta didik menunjukan bahwa bahan ajar fisika untuk kurikulum 2013 digunakan sangat bermanfaat, dengan adanya modul berbasis discovery learning, peserta didik dapat termotivasi untuk mempelajari dan menyiapkan diri sebelum pembelajaran dimulai didalam kelas, dapat memudahkan siswa dalam memahami materi pembelajaran secara mandiri, meringatkan beban peserta didik karena modul tidak perlu dibeli dalam bentuk cetak, serta mendukung gerakan Go Green dalam upaya mengurangi efek pemanasan global karena mengurangi penggunan kertas.

Pada saat ini pembelajran dilakukan secara daring dikarenakan wabah covid-19 yang mengakibatkan penggunan teknologi sangat dibutuhkan, guru dituntut untuk kreaktif dalam menyampaikan materi pelajaran supaya tujuan pembelajaran tercapai. Untuk mempermudah penyampaian materi secara jarak jauh maka diperlukan alat untuk memfasilitasinya. Salah satunya yaitu e-modul yang didesain khusus untuk mempermudah pendidik menyampaikan materi ajar dan 
Nini Sonia, Nila Kesumawati, Nora Sulmilasari : Pengembangan E-Modul ...

menjadikan siswa lebih aktif dan mandiri. Oleh karena itu, diperlukan upaya yang nyata dan tepat agar siswa lebih aktif dan mandiri. Salah satu upaya yang dapat dilakukan adalah mengembangkan sebuah modul elektronik yang berkualitas berbasis discovery learning.

\section{METODE PENELITIAN}

Jenis penelitian yang digunakan dalam penelitian ini adalah metode penelitian dan pengembangan (Research and Development). Research and Development adalah metode penelitian yang digunakan untuk meghasilkan produk dan menguji valid atau tidak valid produk yang telah dihasilkan (Sugiyono, 2014). Produk yang dihasilkan dalam penelitian ini adalah media pembelajaran E-Modul Berbasis Discovery Learning Pada Pembelajaran Tematik Tema 6 Subtema 1 Hewan Di Sekitarku Kelas II SD. Desain pengembangan yang digunakan pada penelitian ini adalah pengembangan ADDIE yang merupakan singkatan dari Analysis, Desing, Development or Prooduction, Implementation or Delivery and Evaluation.

ADDIE terdiri dari: Analysis (Analisis), Design (perancangan), Development (pengembangan), Implementation (penerapan), Evaluation (Evaluasi) Teknik pengumpulan data dalam penelitian pengembangan $e$-modul ini menggunakan beberapa jenis, yaitu wawancara, dokumentasi, kuesioner (angket). Teknik analisis data dilakukan untuk mendapatkan media pembelajaran berupa modul berkualitas yang memenuhi kriteria kevalidan, kepraktisan dan analisis Keefektifan.

\section{HASIL PENELITIAN DAN PEMBAHASAN}

Pada tahap analisis data validasi ini dilakukan berdasarkan hasil dari penyebaran angket validasi yang telah diisi oleh validator sesuai dengan aspek penilaian bagi ahli/pakar materi matematika yaitu kelayakan isi, kelayakan penyajian, sedangkan untuk ahli media yaitu kelayakan kegrafisan, kelayakan bahasa, dan untuk pendidik/guru yaitu aspek perumusan tujuan pembelajaran, aspek kegrafisan, materi dan bahasa. Adapun hasil analisis lembar angket validasi dari tiga validator yang telah ditunjuk sebelumnya dapat dilihat pada tabel dibawah ini.

Tabel 1. Analis is Angket Validasi

\begin{tabular}{l|l|l}
\hline No. & Validator & Rata-Rata \\
\hline 1. & Validator 1 & $80 \%$ \\
\hline 2. & Validator 2 & $91 \%$ \\
\hline 3. & Validator 3 & $95 \%$ \\
\hline Jumlah & $\mathbf{2 6 6}$ \\
\hline \multicolumn{2}{l}{ Rata-Rata } & $\mathbf{8 8 , 6 6 \%}$ \\
\hline
\end{tabular}

Dari hasil validasi kepada ketiga validator mendapatkan nilai rata-rata sebesar $88,66 \%$. Berdasarkan kriteria interprestasi skor pada tabel 3.4 (BAB III hal 40 ) dapat ditarik kesimpulan bahwasanya e-modul yang telah dikembangkan sebelumnya dikategorikan valid serta dapat 
digunakan untuk proses pembelajaran baik sekolah maupun secara umum.

\section{a. Hasil Analisis Data Angket Respon Siswa}

Setelah siswa yang dijadikan subjek penelitian setelah selesai menggunakan/mempraktekkan bahan ajar e-modul di kelas II yang telah dikembangkan, seluruh siswa yang ada di kelas II tersebut diberikan angket respon yang dimaksudkan untuk memberikan penilaian terhadap bahan ajar e-modul yang telah dikembangkan sebelumnya oleh peneliti. Hasil angket siswa dapat diuraikan pada tabel berikut ini.

\section{Tabel 2. Hasil Angket Respon Siswa}

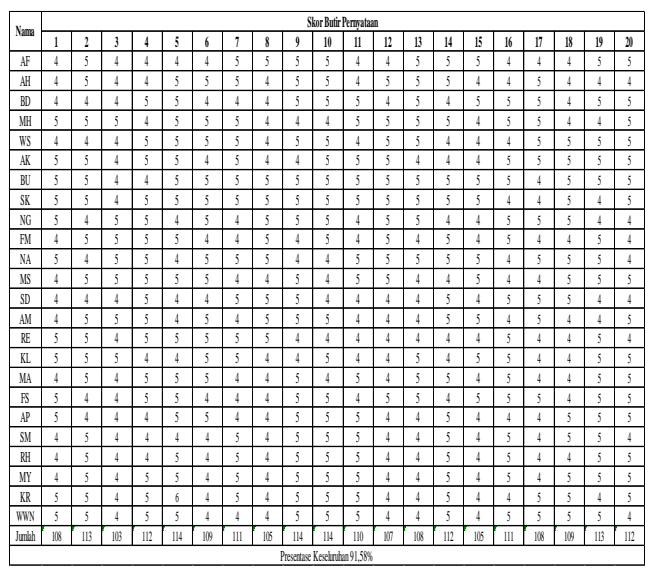

Tabel 9 diatas merupakan data hasil lembar respon angket siswa yang telah dilakukan sebelumnya dengan memperoleh presentase nilai rata-rata sebesar 91,58 \%. Dapat ditarik kesimpulan bahwan bahan ajar $e$-modul yang telah dikembangkan oleh peneliti dikategorikan praktis.

\section{b. Hasil Analisis Uji Tes Soal Siswa}

Setelah melakukan berbagai proses panjang mulai dari mendesain produk, tahap validasi produk kepada para ahli/pakar serta melakukan uji coba bahan ajar e-modul kepada siswa, untuk mengetahui efek potensial dari produk tersebut maka peneliti melakukan uji tes soal yang berkaitan dengan materi pecahan yang dikembangkan oleh peneliti, seluruh siswa yang ada di kelas $\mathrm{v}$ diberikan lembar soal yang terdiri dari 10 (soal) berbentuk esai. Hal tersebut dimaksudkan untuk mengetahui hasil belajar siswa menggunakan bahan ajar e-modul yang telah dikembangkan oleh peneliti. Hasil skor nilai siswa dapat di uraikan pada tabel dibawah ini.

Tabel 3. Hasil Uji Tes Siswa

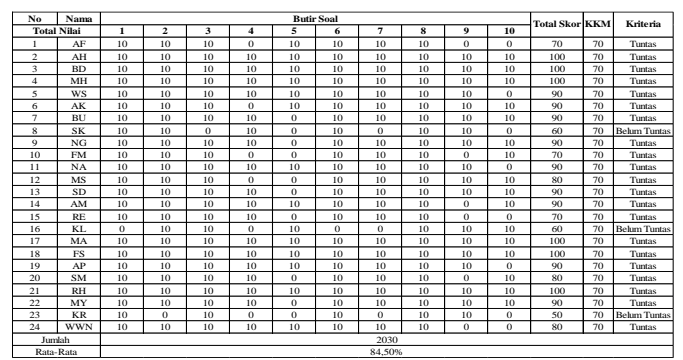

Berdasarkan data skor tes halis uji tes soal siswa diatas, didapatkan nilai rata-rata sebesar $84,50 \%$. Mengacu berdasarkan kriteria interpretasi skor kelayaan analisis hasil belajar siswa memiliki efek potensial sebesar 84,50\% dikategorikan kedalam hasil belajar yang sangat baik/sangat valid / sangat menarik. 
Nini Sonia, Nila Kesumawati, Nora Sulmilasari : Pengembangan E-Modul ...

\section{Pembahasan}

Bahan ajar yang dikembangkan iyalah bahan ajar yang berbentuk $e$ modul yang berisikan materi pecahan matematika yang ada di kelas II dan menghasilkan e-book yang valid, praktis dan efek potensial. Hal ini sejalan dengan penelitian yang dilakukan oleh Isnia, 2020 dengan hasil Hasil peneliti yang diperoleh dari uji kelayakan rata-rata persentase sebesar 94,16\% dari dosen ahli bahan ajar $82,36 \%$ dari dosen ahli materi. Uji keparktisan diperoleh $92,75 \%$ dari guru dan $84,79 \%$ dari siswa dan uji keefektifan diperoleh nilai 81.berdasarkan perolehan hasil nilai hasil tersebut maka e-modul tema 6 subtema berbasis issnkuiri dinyatakan layak digunakan untuk sekolah dasar.

Penelitian ini dilakukan secara langsung/tatap muka dengan siswa yang ada di SDN 199 Palembang. Penelitian ini dilakukan 3 kali pertemuan dengan siswa uji coba yang berbeda, mulai dari Small Group, dan Kelompok Besar. Setiap melakukan penelitian di kelas siswa sangat antusias, untuk belajar dan menggunakan bahan ajar e-modul tersebut, itu dapat dilihat dari cara mereka aktif untuk bertanya pada materi pecahan dan mereka sangat bersemangat untuk belajar karna menggunakan metode baru seperti belajar menggunakan infokus, HP, saat di kelas, serta respon siswa terhadap bahan ajar e-modul yang telah dikembangkan sangat baik, baik secara lisan langsung disampaikan maupun tertulis pada saat uji coba produk yang dilakukan. Alasan siswa antusias dalam belajar menggunakan e-modul ini dikarenakan siswa anggap menarik karna dalam e-modul tersebut berisikan vidio penjelasan tentang cara menghitung materi pecahan dan berbeda metode dalam cara siswa yang telah diberikan guru sebelumnya.

Penyajian data dalam penelitian ini terbagi menjadi 3 antara lain: (1) penyajian data dari hasil validasi yang diperoleh dari validator sebelumnya dengan memberikan lembar validasi wolkroup dan angket validasi, (2) penyajian data dari dari hasil ujicoba kelompok kecil (small grrup) dan kelompok besar yang diperoleh melalui respon angket siswa yang telah diisi oleh siswa sebelumnya, dan (3) penyajian data dari hasil uji tes soal kepada siswa, data tersebut diperoleh melalui hasil kerja siswa dalam mengerjakan soal yang telah diberikan oleh peneliti.

Dari hasil penelitian yang telah dilakukan, maka untuk itu peneliti mendapat nilai hasil dari lembar angket respon siswa yang telah di isi oleh siswa yang digunakan sebagai subjek dengan keseluruhan siswa 1 (satu) kelas yang berjumlah 24 orang siswa yang ada di kelas II memperoleh nilai rata-rata sebesar 91,58 \% dan juga disertakan tanggapan siswa mengenai e-modul yang telah dikembangkan oleh peneliti. Sedangkan hasil rata-rata kevalidan dari para validator yang diperoleh dari niali hasil angket validasi sebesar $84,50 \%$, dengan masing- masing setiap validator 1 sebesar $80 \%$, validator $91 \%$, dan 
validator 3 sebesar $95 \%$. Berdasarkan nilai rata-rata yang diperoleh dari lembar angket validasi dapat disimpulkan bahwa e-modul dapat dikatakan valid dan praktis. Sedangkan hasil nilai rata-rata efek potensial yang didapat melalui uji tes soal kepada siswa sebesar 84,50\% dapat disimpulkan bahwa bahan ajar e-modul sangat efek potensial. Berdasarkan hasil pengembangan $e$ modul pada tematik tema 6 yang ada pada kelas II sekolah dasar, mulai dari Prototype I, Prototype II, dan Prototype III dapat diuraikan sebagai berikut:

\section{1) Validitas}

Dari hasil validasi Prototype 1 bersama pakar/ahli maka dilakukan revisi sesuai dengan komentar dan saran sehingga ahli sehingga mendapatkan Prototype II. Pada prototype II kembali divalidasi kepada pakar dengan menyertakan lembar angket validasi guna untuk memberikan peniaian terhadap produk yang telah direvisi oleh peneliti. Setelah mendapatkan penilaian dari para ahli selanjutnya melakukana perhitungan kevalidan berdasarkan presentase interprestasi skor, peneliti memperoleh nilai ratarata total validasi sebesar $8,66 \%$ berdasarkan presentase nilai yang diperoleh berada diantara 80,00\%$100 \%$ maka dapat disimpulkan produk bahan ajar e-modul yang telah dikembangkan oleh peneliti dapat dikatakan valid.

Sejalan dengan penelitian terdahulu relevan yang dilakukan oleh
Komang Wisnu Baskara Putra (2017) menghasilkan e-modul menghasilkan rancangan dan mengimplementasikan hasil rancangan e-modul yang berbasis discovery learning pada mata pelajran sistem komputer, untuk mengetahui sistem respon guru dan siswa terhadap pengembangan emodul berbasis model pembelajaran discovery learning pada mata pelajaran sistem komputer. Hasil penelitian yang diperoleh terlihat bahwa (1) hasil rancangan dan impelemntasi e-modul berbasis model pembelajran discovery learning yang telah dikembangkan dinyatakan berhasil diterapkan berdasarkan beberapa uji yang dilakukan (2) hasil analisis respon guru menunjukan bahwa didapatkan rata-rata skor respon sebesar 41, jika dikonversikan ke dalam tabel pengolongan respon maka termasuk pada katagori positif. Sedangkan untuk respon siswa terhadap pengembangan e-modul sebesar 64,74, jika dikonvirsikan kedalam tabel pengolongan respon siswa termasuk katagori positif.

\section{2) Praktis}

Bahan Ajar E-modul yang telah dilakukan proses validasi kepada para pakar/ahli sehingga menghasilkan prototype II dan dinyatakan valid maka dilakukan uji coba kelompok kecil (small group) setelah kelompok kecil selesai di uji cobakan dilanjutkan dengan uji coba kelompok besar. Berdasarkan data yang diperoleh dari hasil angket respon siswa selama uji coba produk yang telah dilakukan, peneliti memperoleh 
Nini Sonia, Nila Kesumawati, Nora Sulmilasari : Pengembangan E-Modul ...

rata-rata total angket respon siswa sebesar 91,58 \% dalam hal ini presentase rata-rata yang telah didapat berada diantara $80,00 \%$ - $100 \%$ maka dapat disimpulkan bahwa e-modul yang telah dikembangkan oleh peneliti dikategorikan sangat praktis dan dapat digunakan. Sehingga emodul ini sesuai dengan teori menurut (Hasjiandito, 2016) yang menyatakan bahwa media pembelajaran dapat membuat peserta didik mempermudah dalam proses kegiatan pembelajaran dikelas.

Sejalan dengan penelitian Isnia, 2020 Hasil peneliti yang diperoleh dari uji kelayakan rata-rata persentase sebesar 94,16\% dari dosen ahli bahan ajar 82,36\% dari dosen ahli materi. Uji keparktisan diperoleh $92,75 \%$ dari guru dan $84,79 \%$ dari siswa dan uji keefektifan diperoleh nilai 81.berdasarkan perolehan hasil nilai hasil tersebut maka e-modul tema 6 subtema berbasis issnkuiri dinyatakan layak digunakan untuk sekolah dasar.

\section{3) Efek potensial}

Efek potensial dari bahan ajar $e$ modul yang telah dikembangkan oleh peneliti dalam tes dapat diketahui berdasarkan ketuntasan KKM , siswa yang tuntas dalam tes ini terdiri dari 21 siswa dan 3 orang siswa tidak mencapai nilai KKN. Dari hasil tes soal yang telah dilakukan peneliti memperoleh nilai rata - rata efek potensial sebesar $84,50 \%$, dalam hal ini presentase rata-rata yang telah didapat berada diantara $80,00 \%$ $100 \%$ maka dapat disimpulkan bahwa e-modul yang telah dikembangkan oleh peneliti dikategorikan sangat efek potensial untuk dapat digunakan.

Hal tersebut sesuai dengan teori yang dikemukakan oleh (Arsyad, 2014) yang menyatakan bahwa suatu media pembelajaran dapat meningkatkan hasil belajar siswa berdasarkan penyajian dan informasi yang jelas suatu media pembelajaran. Hal ini juga sejalan dengan penelitian yang dilakukan oleh Asmawati (2019), hasil dari penelitian dan pengemmbangan ini perencanaan berupa cara membuat e-modul matematika. Hasil tahap 1 pengujian kelayakan ahli materi sebesar 3,82 dan 76,40\%, bahasa sebesar 3,75 dan $75 \%$, ahli media 3,83 dan $76,60 \%$, dan uji coba lapangan sebesar 81,6\%, sehingga rata-rata skor yang diperoleh sehingga 3,8 dan $77,4 \%$ dengan katagori cukup , kemudian dilakukan uji tahap 2 ahli materi sebesar 4,61, dan $92,2 \%$ ahli bahsa 4,4 dan $88,33 \%$, ahli media sebesar 4,03 dan $80,7 \%$ dan uji lapangan sebesar 83,52\%, sehingga rata-rata skor 4,34 dan $86,18 \%$ dengan katagori "layak" selanjutnya diadakan tes tertulis dengan rata-rata nilai post-test pada revisi produk akhir adalah 75 . Sehingga produk yang dikembangkan layak digunakan dalam pembelajaran. Hal ini sesuai dengan penelitian yang dilakukan oleh (Aprianti, Desnita \& Budi, 2015) yang menyatakan bahwa media pembelajaran berupa e-modul dapat digunakan sebagai bahan alternatif yang dapat meningkatkan minat dan hasil belajar peserta didik. Dapat disimpulkan bahwa e-modul berbasis discovery learning yang telah 


\section{SCHOOL EDUCATION JOURNAL VOLUME 11 NO. 4 DESEMBER 2021}

dikembangkan mempunyai efek potensial yang dapat digunakan pada proses pembelajaran dikelas.

\section{SIMPULAN}

Penelitian pengembangan $e$ modul modul berbasis discovery learnig yang telah dilakukan dengan menggunakan model ADDIE (Analysis, Desing, Development or Prooduction, Implementation or Delivery and Evaluation) menghasilkan pengembangan bahan ajar berbentuk e-modul berbasis discovery learnig yang ada di kelas II di SD Negeri 199 Palembang adalah valid. Hal ini diperkuat dengan diperolehnya persentase hasil analisis nilai rata-rata kevalidan dari validator melalui lembar angket validasi sebesar 88,66 \%. Hasil pengembangan bahan ajar berbentuk e- modul berbasis discovery learnig yang ada di kelas II adalah praktis. Hal ini diperkuat dengan diperolehnya hasil analisis persentase nilai rata-rata kepraktisan yang telah didapat dari siswa uji coba lembar angket siswa sebesar 91,58\%. Hasil pengembangan bahan ajar berbentuk e-modul berbasis discovery learnig yang ada di kelas II adalah adalah efek potensial. Hal ini diperkuat dengan diperolehnya hasil analisis persentase nilai rata-rata dari efek potensial yang telah didapat dari siswa uji coba melalui uji tes soal sebesar 84,50\%.

Berdasarkan hasil yang telah dikembangkan oleh peneliti yang berjudul pengembangan e-modul berbasis discovery learning pada pembelajaran tematik tema 6 subtema 1 hewan di sekitarku SD kelas II dapat disimpulkan bahwa e-modul yang telah dikembangkan layak untuk digunakan dalam proses pembelajaran yang akan dilakukan.

\section{DAFTAR RUJUKAN}

Arikunto,S dan Jabar, C.A. 2014.

Evaluasi Program Pendidikan;

Pedoman Teoritis Praktis Bagi

Mahapeserta didik dan Praktisi

Pendidikan. Jakarta: Bumi

Aksara.

Asmawati, S. $\quad$ H. 2019.

Pengembangan E-Modul

Matematika untuk siswa SD.

Teknologi Pembelajran

Pascasarjana Universitas Sulatan

Ageng Tritasya.

Asrohah. 2014. Pembelajaran

Tematik. Jakarta: Rajawali Pers.

Budiarti, W. N., \& dkk. 2021.

Pengembangan Modul Elektronik

(E MODUL) Keterampilan

Berbahasa Dan Sastra Indonesia

SD Untuk Meningkatkan

Keterampilan. Elemntary School,

Vol.1.

Febrianti, K. V., \& dkk. 2017. Pengembangan Modul Digital

Fisika Berbasis Discovery

Learning Pada pokok Bahasan

Kinematika Gerak Lurus. Jurnal

Wahana Fisika, Vol.2, 18-26.

Fhina Haryanti, B. A. 2016. Pengembangan Modul

Matematika Berbasis Discovery

Learning Berbantuan Flipbook

Maker Untuk Meningkatkan

Kemampuan Pemahaman Konsep

Pada Materi Segitiga. Jurnal 
Nini Sonia, Nila Kesumawati, Nora Sulmilasari : Pengembangan E-Modul ...

Pendidikan Matematika

Universitas Pgri Semarang,

Vol.1.

Hamdani. 2011. Strategi Belajar

Mengajar. Bandung: Pustaka

Setia.

Imelda Uma Riwu, d. 2018.

Pengembangan Bahan Ajar

Elktronik Bermuatan Multimedia

Pada Tema Peduli Terhadap

Mahluk Hidup Untuk Siswa

Sekolah Dasar Kelas IV Di

Kabupaten Ngada. Jurnal of

Education Technolgy, Vol.2 (2)

pp 56-64.

Iren Maria Juli Astuti, F. S. 2017.

Buku Tematik 2013 Tema 6 Merawat Hewan Dan Tumbuhan.

Jakarta: KDT.

Isnia, H. W. 2020. Pengembangan emodul Tema 6 subtema 1 berbasis issnkuiri untuk siswa kelas III Sekolah Dasar. Malang : Universitas Kanjuruhan Malang Indonesia, Vol.4.

Komang Wisnu Baskara Putra, M. A. 2017. Pengembangan E-Modul Berbasis Model Pembelajaran Discovery Learning Pada Mata Pelajaran "Sistem Komputer" Untuk Siswa Kelas X Multimedia
SMK Negeri 3 Singaraja.

Bandung: Pendidikan Teknologi dan Kejuruan Universitas Pendidikan Ganesha, Vol.14.

Kuncahayo. 2018. Pengembangan emodul atau (modul digital) dalam pembelajaran tematik disekolah dasar. Malang: Universitas Muhamadiyah malang.

Mulyatiningsih, E. 2014. Metode penelitian terapan bidang pendidikan. Bandung: Alfabeta.

Prastowo, A. 2014. Pengembangan Bahan Ajar Tematik. Jakarta: Kencana.

Rohaeti, e. e. 2019. Pembelajaran Inovatif. Bandung: Alfabeta.

Sugiyono. 2012. Metode Penelitian Pendidikan

(Pendekatan

Kuantitatif, Kualitatif, dan $R \& D)$. Bandung: Alfabeta.

Sulistyosari, Y. 2018. Kreaktivitas Guru Dalam Mengembangkan Bahan Ajar IPS Pada SMP/MTS Se-kecamatan Ngadirejo Kabupaten Temanggung. Harmony, Vol.3.

Zainal, A. 2011. Konsep dan model pengembangan kurikulum. Bandung : Remaja Rosdakarya. 